\title{
Ecosystem Services in Urban Environments
}

Sarah

University of Greenwich, London, United Kingdom

\section{Introduction}

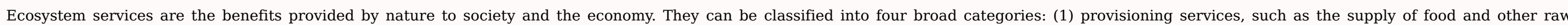

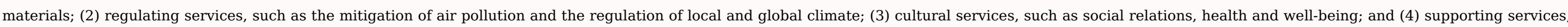

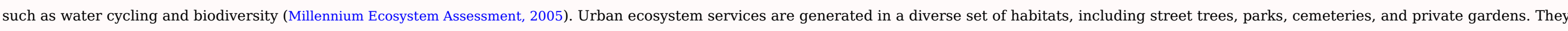
are also generated by engineered green infrastructure, such as sustainable urban drainage systems, green roofs, and vertical greening systems.

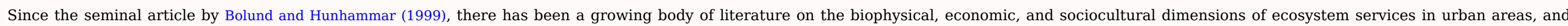

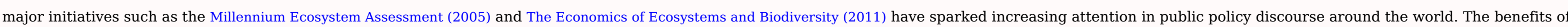

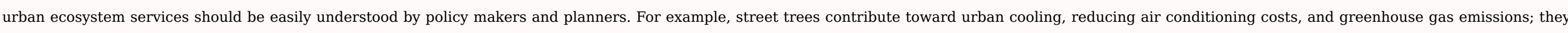
contribute to climate

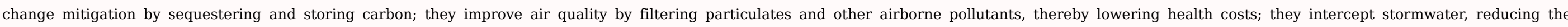

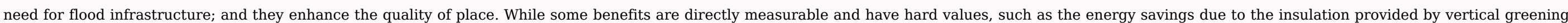
systems, others are not so readily measurable and these soft values are difficult to estimate, such as the health benefits of a rooftop garden.

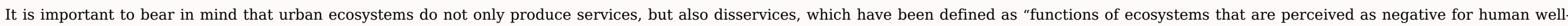

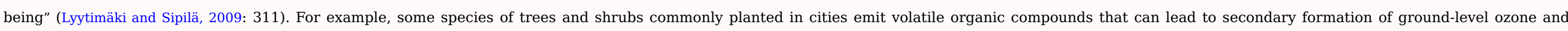
indirectly contribute to urban smog, while some wind-pollinated plants can cause allergic reactions. The costs of disservices such as these can also be measured and valued.

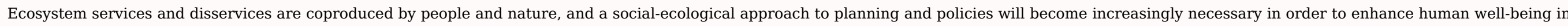

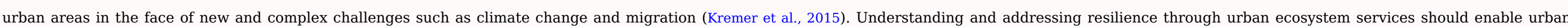

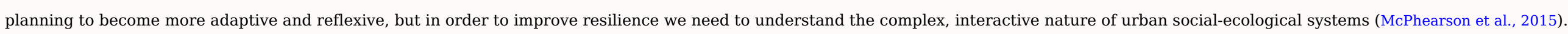

\section{Provisioning Services}




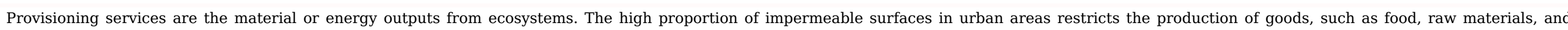

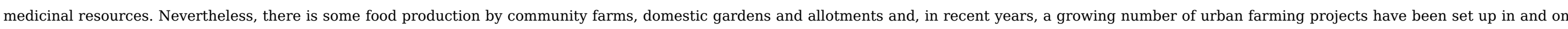

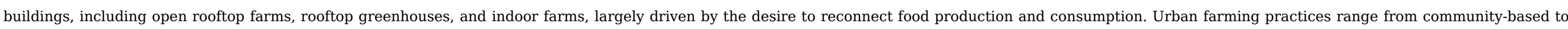

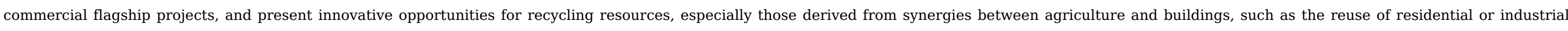
wastewater, waste heat, and organic waste (Ackerman et al., 2014; Buehler and Junge, 2016; Specht et al., 2014; Thomaier et al., 2014).

Page 19

\section{Regulating Services}

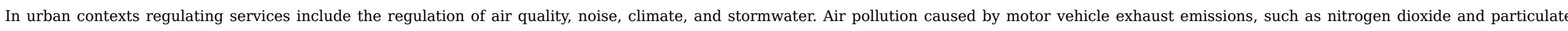

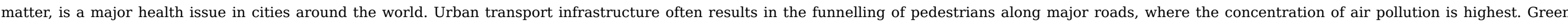

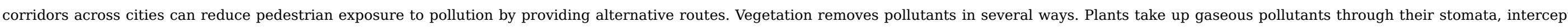

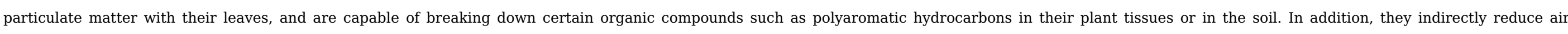

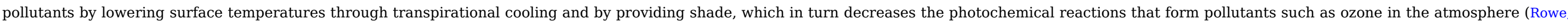
2011).

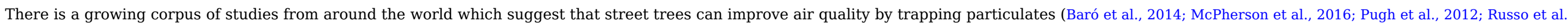

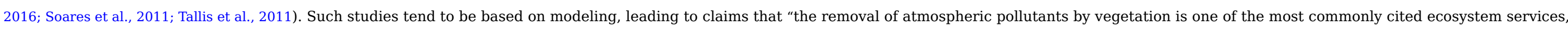

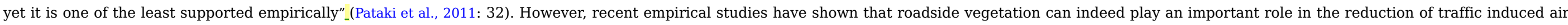

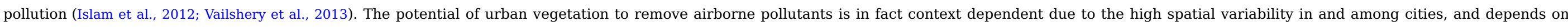

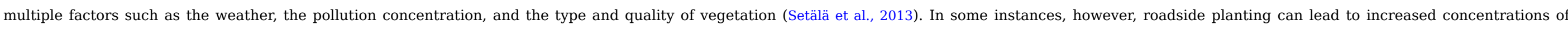

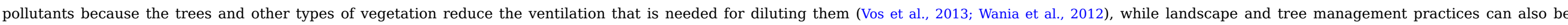
polluting (Escobedo et al., 2011; Roy et al., 2012).

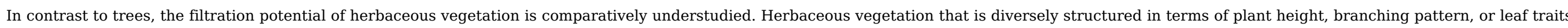

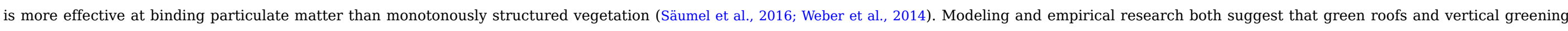

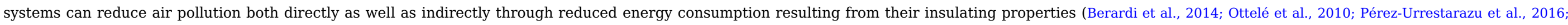
Rowe, 2011; Vijayaraghavan, 2016).

Page 20

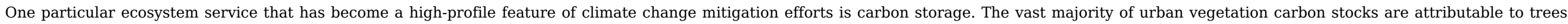

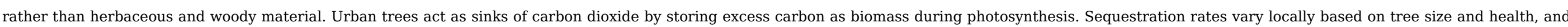

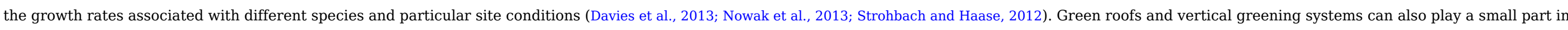

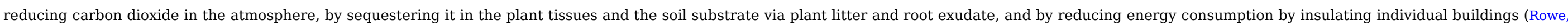
2011). 


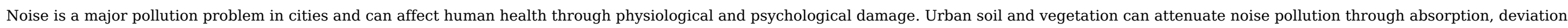

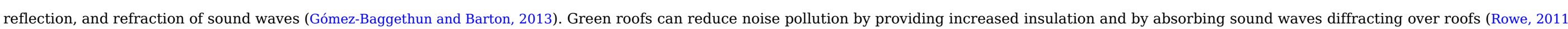

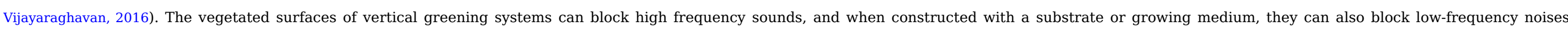
(Azkorra et al., 2015; Pérez et al., 2016).

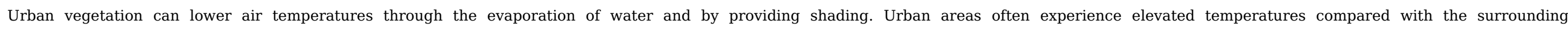

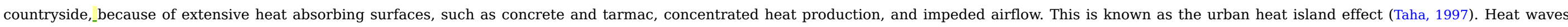

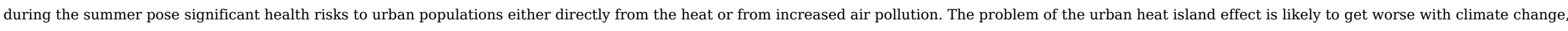

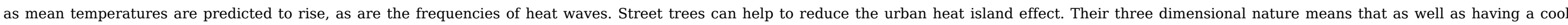
canopy, they also shade adjacent areas, which lowers the surface temperature of the shaded area and reduces the storage and convection of heat (Armson et al., 2012).

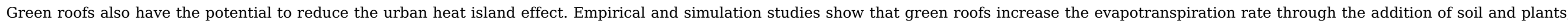

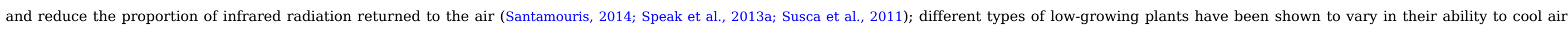
temperatures (Blanusa et al., 2013). While the contribution of green roofs to mitigating heat stress at the pedestrian level is negligible (Alcazar et al., 2016; Zölch et al., 2016),

Page 21

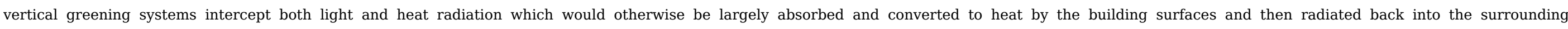

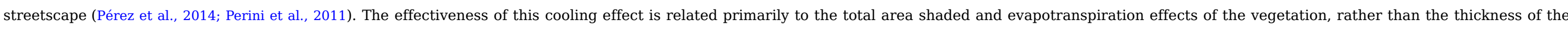

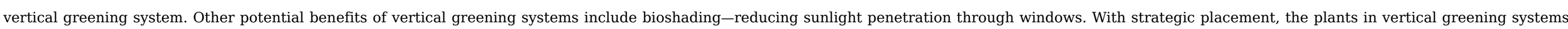
can also create enough turbulence to break vertical airflow, which slows and cools down the air (Pérez-Urrestarazu et al., 2016).

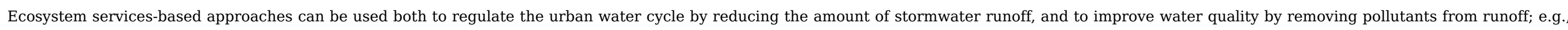

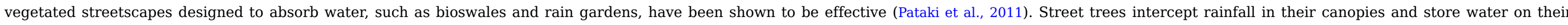

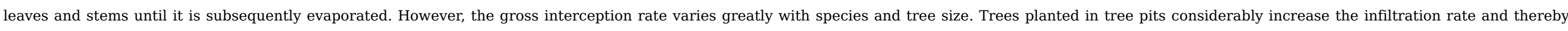

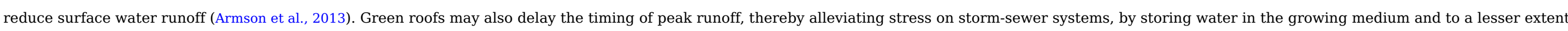

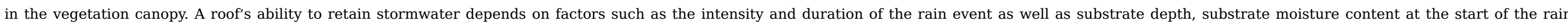

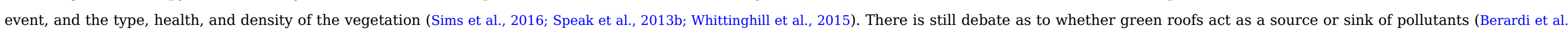

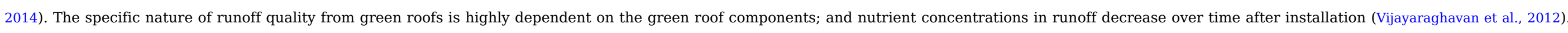

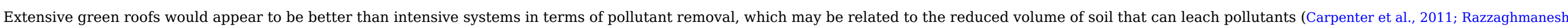
et al., 2014),

\section{Cultural Services}

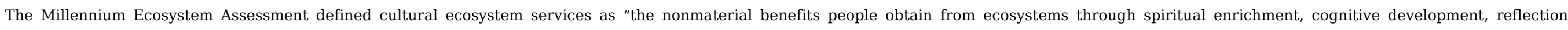

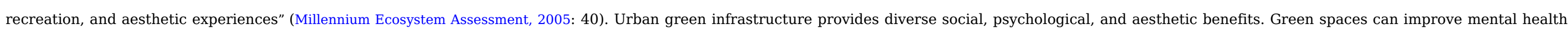
and the quality of community life, and researchers have observed a link between increasing urbanization and 


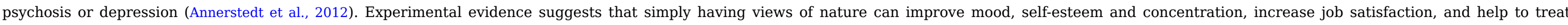
stress and mental health disorders (Depledge et al., 2011; Douglas, 2012; Peckham et al., 2013).

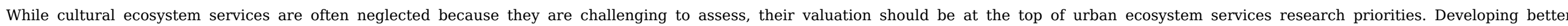

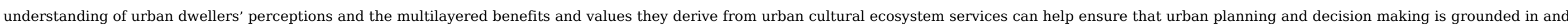

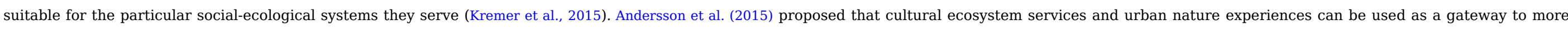

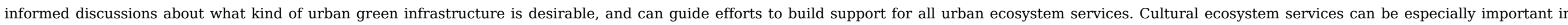

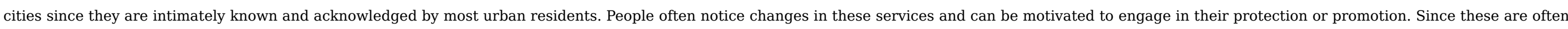
bundled with other ecosystem services, engaging in their stewardship will implicitly include these as well (Ernstson, 2013).

\section{Supporting Services}

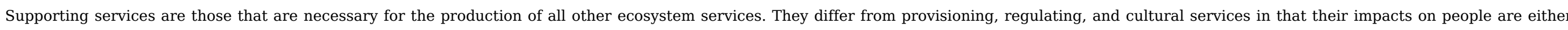

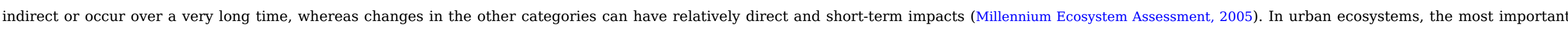

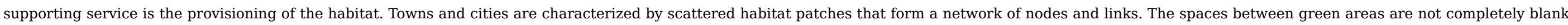

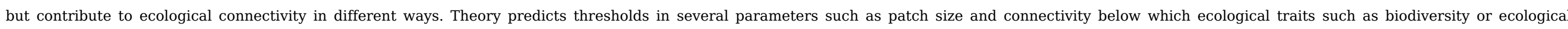

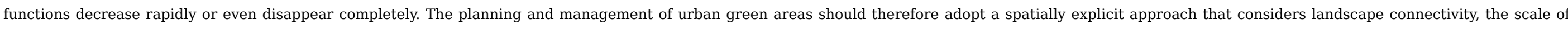

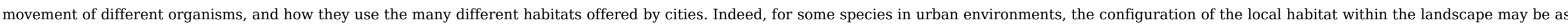
critical as the composition of the local habitat itself (Andersson and Bodin, 2008; Braaker et al., 2014).

Page 23

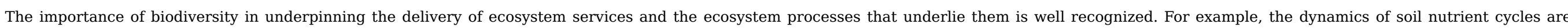

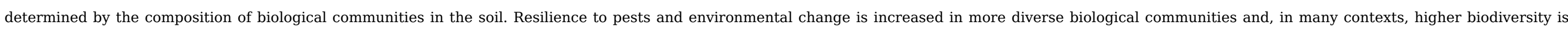

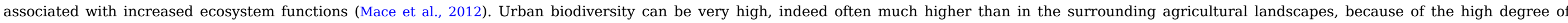
heterogeneity of urban ecosystems which are characterized by a mosaic of different habitats (Andersson et al., 2014).

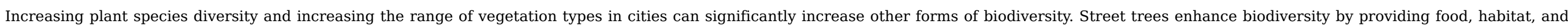

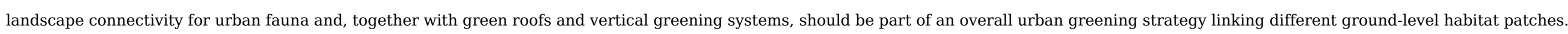

\section{The Value of Ecosystem Services}

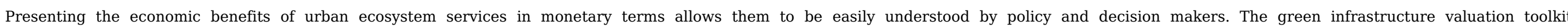

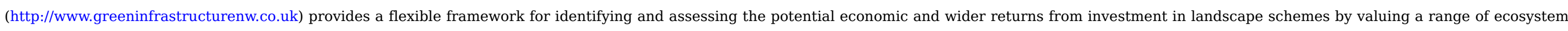

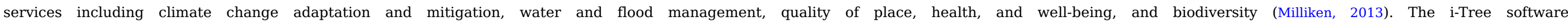

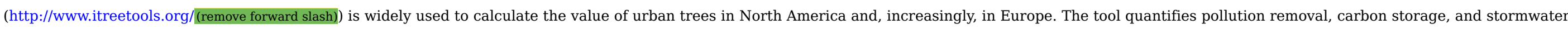

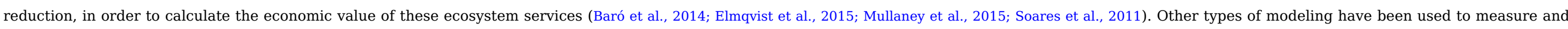




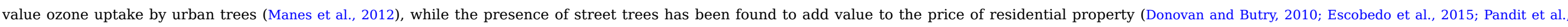
2013).

\section{Conclusion}

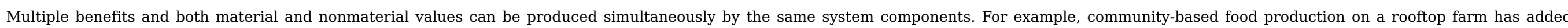
benefits such as regulating stormwater, enhancing biodiversity, improving human health and well-being, and fostering social cohesion. Conceiving of the multiple kinds

Page 24

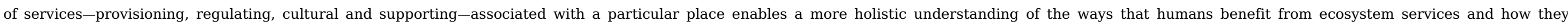
can be synergistically managed (Andersson et al., 2015).

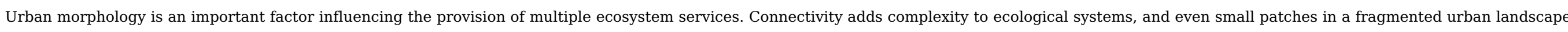

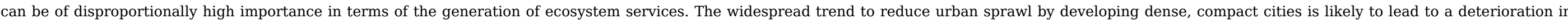

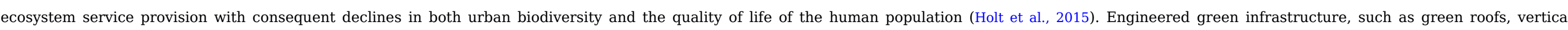

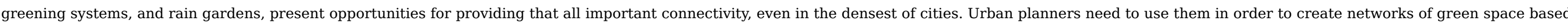

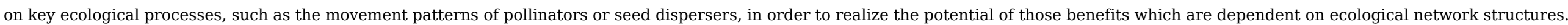

\section{References}

Ackerman K., Conard M., Culligan P., Plunz R., Sutto M.P. and Whittinghill L., Sustainable food systems for future cities: the potential of urban agriculture, Econ. Soc. Rev. 45, 2014 , 189-206.

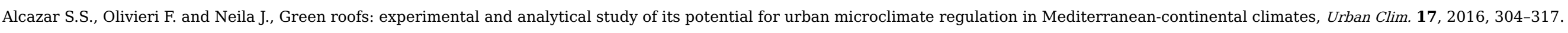

Andersson E. and Bodin O., Practical tool for landscape planning? An empirical investigation of network based models of habitat fragmentation, Ecography 32, $2008,123-132$.

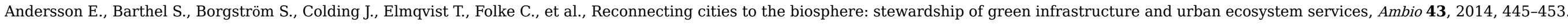
Andersson E., Tengö M., McPhearson T. and Kremer P., Cultural ecosystem services as a gateway for improving urban sustainability, Ecosyst. Serv. 12, $2015,165-168$.

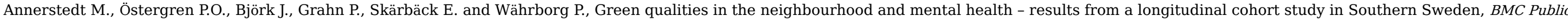
Health 12, 2012, 337. https://doi.org/10.1186/1471-2458-12-337.

Armson D., Stringer P. and Ennos A.R., The effect of tree shade and grass on surface and globe temperatures in an urban area, Urban For. Urban Gree. 11, 2012, 245-255.

Armson D., Stringer P. and Ennos A.R., The effect of street trees and amenity grass on urban surface water runoff in Manchester, UK, Urban For. Urban Gree. 12, 2013, 282-286.

Azkorra Z., Pérez G., Coma J., Cabeza L.F., Bures S. and Álvaro J.E., Evaluation of green walls as a passive acoustic insulation system for buildings, Appl. Acoust. 89, 2015 , 46-56.

Page 25 
Spain, Ambio 43, 2014, 466-479.

Berardi U., GhaffarianHoseini A.H. and GhaffarianHoseini A., State-of-the-art analysis of the environmental benefits of green roofs, Appl. Energy 115, $2014,411-428$.

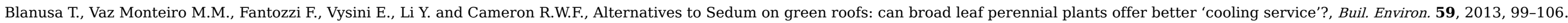
Bolund P. and Hunhammar S., Ecosystem services in urban areas, Ecol. Econ. 29, 1999, 293-301.

Braaker S., Ghazoul J., Obrist M.M. and Moretti M., Habitat connectivity shapes urban arthropod communities: the key role of green roofs, Ecology 95, $2014,1010-1021$.

Buehler D. and Junge R., Global trends and current status of commercial urban rooftop farming, Sustainability 8, 2016, 1108. https://doi.org/10.3390/su8111108.

Carpenter D.D. and Kaluvakolanu P., Effect of roof surface type on stormwater run-off from full-scale roofs in a temperate climate, J. Irrigat. Drain. Eng. 137, 2011, 161-169.

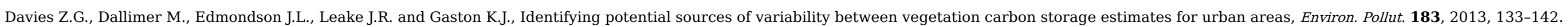

Depledge M.H., Stone R.J. and Bird W.J., Can natural and virtual environments be used to promote improved human health and wellbeing?, Environ. Sci. Technol. 45, 2011, 4660-4665.

Donovan G.H. and Butry D.T., Trees in the city: valuing street trees in Portland, Oregon, Landscape Urban Plan. 94, 2010, 77-83.

Douglas I., Urban ecology and urban ecosystems: understanding the links to human health and well-being, Curr. Opin. Environ. Sustain. 4, 2012, 385-392.

Elmqvist T., Setälä H., Handel S.N., van der Ploeg S., Aronson J., Blignaut J.N., et al., Benefits of restoring ecosystem services in urban areas, Curr. Opin. Environ. Sustain. 14, 2015, 101-108.

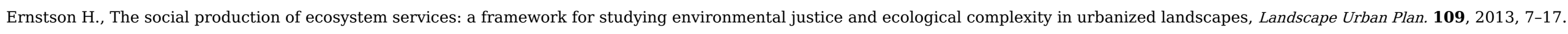

Escobedo F.J., Kroeger T. and Wagner J.E., Urban forests and pollution mitigation: analyzing ecosystem services and disservices, Environ. Poll. 159, $2011,2078-2087$.

Escobedo F.J., Adams D.C. and Timilsina N., Urban forest structure effects on property value, Ecosyst. Serv. 12, 2015, 209-217.

Gómez-Baggethun E. and Barton D.N., Classifying and valuing ecosystem services for urban planning, Ecol. Econ. 86, 2013, $235-245$.

Holt A.R., Mears M., Maltby M. and Warren P., Understanding spatial patterns in the production of multiple urban ecosystem services, Ecosyst. Serv. 16, $2015,33-46$.

Islam M.N., Rahman K.S., Bahar M.M., Habib M.A., Ando K. and Hattori N., Pollution attenuation by roadside greenbelt in and around urban areas, Urban For. Urban Gree. 11, $2012,460-464$.

Kremer P., Andersson E., Elmqvist T. and McPhearson T., Advancing the frontier of urban ecosystem services research, Ecosyst. Serv. 12, $2015,149-151$.

Lyytimäki J. and Sipilä M., Hopping on one leg - the challenge of ecosystem disservices for urban green management, Urban For. Urban Gree. 8, 2009 , 309-315.

Mace G.M., Norris K. and Fitter A.H., Biodiversity and ecosystem services: a multilayered relationship, Trends Ecol. Evolut. 27, $2012,19-26$.

Page 26

Manes F., Incerti G., Salvatori E., Vitale M., Ricotta C. and Costanza R., Urban ecosystem services: tree diversity and stability of tropospheric ozone removal, Ecol. Applicat. 22, 2012, 349-360.

McPhearson T., Andersson E., Elmqvist T. and Frantzeskaki N., Resilience of and through urban ecosystem services, Ecosyst. Serv. 12, 2015, 152-156.

McPherson G., van Doorn N. and de Goede J., Structure, function and value of street trees in California, USA, Urban For. Urban Gree. 17, 2016, 104-115.

Millennium Ecosystem Assessment, 2005. Ecosystems and Human Well-Being: Synthesis. Washington, DC: Island Press. 
Milliken S., The value of green infrastructure in urban design, Urban Des. J. 126, 2013, 18-20.

Mullaney J., Lucke T. and Trueman S.J., A review of benefits and challenges in growing street trees in paved urban environments, Landscape Urban Plan. 134, 2015, 157-166.

Nowak D.J., Greenfield E.J., Hoehn R.E. and Lapoint E., Carbon storage and sequestration by trees in urban and community areas of the United States, Environ. Poll. 178, 2013, 229-236.

Ottelé M., van Bohemen H.D. and Fraaij A.L.A., Quantifying the deposition of particulate matter on climber vegetation on living walls, Ecol. Eng. 36, 2010 , 154-162.

Pandit R., Polyakov M., Tapsuwan S. and Moran T., The effect of street trees on property value in Perth, Western Australia, Landscape Urban Plan. 110, 2013, 134-142.

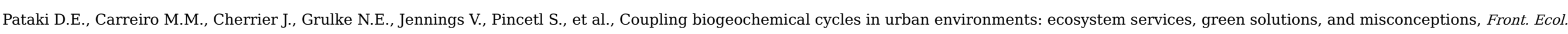
Environ. 9, 2011, 27-36.

Peckham S.C., Duinker P.N. and Ordóñez C., Urban forest values in Canada: views of citizens in Calgary and Halifax, Urban For. Urban Gree. 12, $2013,154-162$.

Pérez G., Coma J., Martorell I. and Cabeza L., Vertical Greenery Systems (VGS) for energy saving in buildings: a review, Renew. Sustain. Energy Rev. 39, $2014,139-165$.

Pérez G., Coma J., Barrenche C., de Gracia A., Urrestarazu M., Burés S., et al., Acoustic insulation capacity of Vertical Greenery Systems for buildings, Appl. Acoust. 110, 2016, 218-226.

Pérez-Urrestarazu L., Fernández-Cañero R., Franco-Salas A. and Egea G., Vertical greening systems and sustainable cities, J. Urban Technol. 22 (4), 2016,1 -21.

Perini K., Ottelé M., Fraaij A.L.A., Haas E.M. and Raiteri R., Vertical greening systems and the effect on air flow and temperature on the building envelope, Buil. Environ. 46, 2011, 2287-2294.

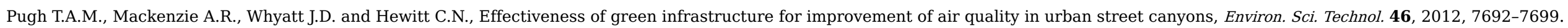

Razzaghmanesh M., Beecham S. and Kazemi F., Impact of green roofs on stormwater quality in a South Australian urban environment, Sci. Total Environ. 470-471, 2014, 651-659.

Rowe D.B., Green roofs as a means of pollution abatement, Environ. Poll. 159, 2011, 2100-2110.

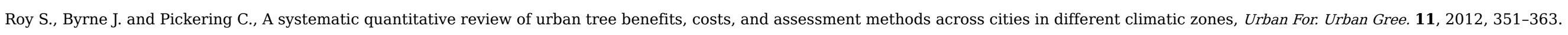

Russo A., Escobedo F.J. and Zerbe S., Quantifying the local-scale ecosystem services provided by urban treed streetscapes in Bolzano, Italy, AIMS Environ. Sci. 3, $2016,58-76$.

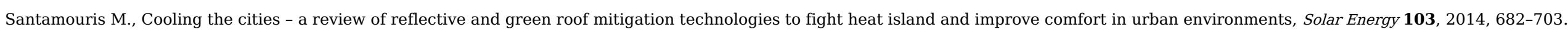

Säumel I., Weber F. and Kowarik I., Toward livable and healthy urban streets: roadside vegetation provides ecosystem services where people live and move, Environ. Sci. Policy 62, 2016, 24-33.

Page 27

Setälä H., Viippola V., Rantalainen A.L., Pennanen A. and Yli-Pelkonen V., Does urban vegetation mitigate air pollution in northern conditions?, Environ. Poll. 183, 2013 , 104-112.

Sims A.W., Robinson C.E., Smart C.C., Voogt J.A., Hay G.J., Lundholm J.T., et al., Retention performance of green roofs in three different climate regions, J. Hydrol. 542, 2016 , 115-124.

Soares A.L., Rego F.C., McPherson E.G., Simpson J.R., Peper P.J. and Xiao Q., Benefits and costs of street trees in Lisbon, Portugal, Urban For. Urban Gree. 10, $2011,69-78$.

Speak A., Rothwell J., Lindley S. and Smith C., Reduction of the urban cooling effects of an intensive green roof due to vegetation damage, Urban Clim. 3, $2013 \mathrm{a}$, 40-55.

Speak A.F., Rothwell J.J., Lindley S.J. and Smith C.L., Rainwater runoff retention on an aged intensive green roof, Sci. Total Environ. 461, 2013b, 28-38.

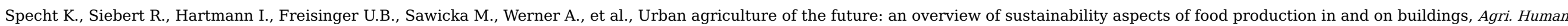
Values 31, 2014, 33-51. 
Strohbach M.W. and Haase D., Above-ground carbon storage by urban trees in Leipzig, Germany: analysis of patterns in a European city, Landscape Urban Plan. 104, 2012, 95-104.

Susca T., Gaffin S.R. and Dell'Osso G.R., Positive effects of vegetation: urban heat island and green roofs, Environ. Poll. 159, $2011,2119-2126$.

Taha H., Urban climates and heat islands: albedo, evapotranspiration, and anthropogenic heat, Energy Buil. 25, 1997, 99-103.

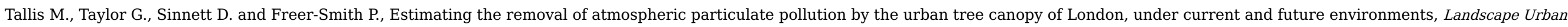
Plan. 103, 2011, 129-138.

The Economics of Ecosystems and Biodiversity, 2011. TEEB Manual for Cities: Ecosystem Services in Urban Management. <www.teebweb.org>

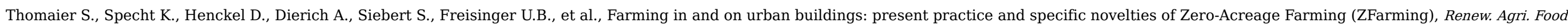
Syst. 30, 2014, 43-54.

Vailshery L.S., Jaganmohan M. and Nagendra H., Effect of street trees on microclimate and air pollution in a tropical city, Urban For. Urban Gree. 12 , 2013 , $408-415$.

Vijayaraghavan K., Greenroofs: a critical review on the role of components, benefits, limitations and trends, Renew. Sustain. Energy Rev. 57, $2016,740-753$.

Vijayaraghavan K.U., Joshi M. and Balasubramanian R., A field study to evaluate runoff quality from green roofs, Water Res. 46, $2012,1337-1345$.

Vos P.E.J., Maiheu B., Vankerkom J. and Janssen S., Improving local air quality in cities: to tree or not to tree?, Environ. Poll. 183, 2013, 113-122.

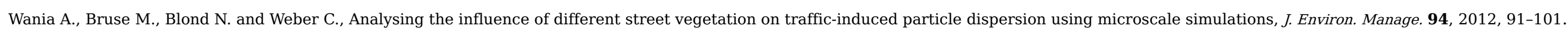

Weber F., Kowarik I. and Säumel I., Herbaceous plants as filters: immobilization of particulates along urban street corridors, Environ. Poll. 186, 2014, 234-240.

Whittinghill L.J., Rowe D.B., Andresen J.A. and Cregg B.M., Comparison of stormwater runoff from sedum, native prairie, and vegetable producing green roofs, Urban Ecosyst. 18, 2015 , 13-29.

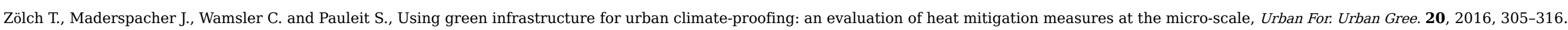
Abstract

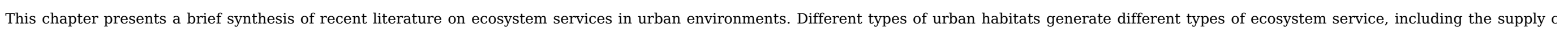

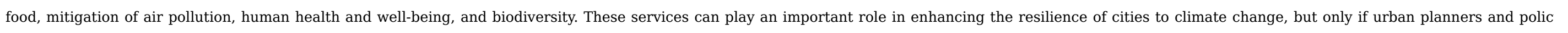

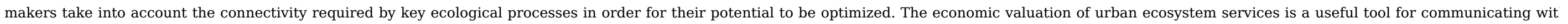
these stakeholders.

Keywords: Ecosystem services; ecosystem disservices; urban environments; social-ecological approach; economic valuation; multiple benefits 